\title{
Article \\ Comparison of Testing Method Effects on Cracking Resistance of Asphalt Concrete Mixtures
}

\author{
Dayong Yang ${ }^{1, *}$, Hamid Reza Karimi ${ }^{2,3}$ and Mohammad Reza Mohammad Aliha ${ }^{2, *}$ \\ 1 School of Transportation Engineering, Shenyang Jianzhu University, Shenyang 110168, China \\ 2 Welding and Joining Research Center, School of Industrial Engineering, \\ Iran University of Science and Technology (IUST), Narmak, Tehran 16846-13114, Iran; \\ karimi_h@civileng.iust.ac.ir \\ 3 School of Civil Engineering, Iran University of Science and Technology, Narmak, Tehran 16846-13114, Iran \\ * Correspondence: yangdy1120@sina.com (D.Y.); mrm_aliha@iust.ac.ir (M.R.M.A.)
}

check for updates

Citation: Yang, D.; Karimi, H.R.; Aliha, M.R.M. Comparison of Testing Method Effects on Cracking Resistance of Asphalt Concrete Mixtures. Appl. Sci. 2021, 11, 5094. https://doi.org/ 10.3390/app11115094

Academic Editors: Cesare Oliviero Rossi and Bagdat Teltayev

Received: 2 May 2021

Accepted: 27 May 2021

Published: 31 May 2021

Publisher's Note: MDPI stays neutral with regard to jurisdictional claims in published maps and institutional affiliations.

Copyright: (c) 2021 by the authors. Licensee MDPI, Basel, Switzerland. This article is an open access article distributed under the terms and conditions of the Creative Commons Attribution (CC BY) license (https:// creativecommons.org/licenses/by/ $4.0 /)$.

\begin{abstract}
As an inherent characteristic of materials, the fracture toughness is an important parameter to study the cracking behavior of asphalt concrete mixtures. Although material compositions and environmental conditions have a significant effect on the fracture toughness, for a certain material and testing environment, the test condition including the specimen configuration and loading type may also affect the obtained fracture toughness. In this paper, the effect of specimen configuration and applied loading type on the measured pure mode-I fracture toughness $\left(\mathrm{K}_{\mathrm{Ic}}\right)$ is investigated. In order to achieve this purpose, using a typical asphalt mixture, four different test specimens including Semi-Circular Bend (SCB), Edge Notch Disc Bend (ENDB), Single Edge Notch Beam (SENB) and Edge Notch Diametral Compression (ENDC) disc are tested under pure mode I. The mentioned specimens have different shapes (i.e., full disc, semi-disc and rectangular beam) and are loaded either with symmetric three-point bending or diametral compressive force. The tests were performed at two low temperatures $\left(-5^{\circ} \mathrm{C}\right.$ and $\left.-25^{\circ} \mathrm{C}\right)$ and it was observed that the critical mode-I fracture toughness $\left(\mathrm{K}_{\mathrm{Ic}}\right)$ was changed slightly (up to $10 \%$ ) by changing the shape of the test specimen (i.e., disc and beam). This reveals that the fracture toughness is not significantly dependent on the shape of the test specimen. However, the type of applied loading has a significant influence on the determined mode I fracture toughness such that the fracture toughness determined by the disc shape specimen loaded by diametral compression (i.e., ENDC) is about $25 \%$ less than the $\mathrm{K}_{\mathrm{Ic}}$ value with the same geometry but loaded with the three-point bending (i.e., ENDB) specimen. In addition, the fracture toughness values of all tested samples were increased linearly by decreasing the test temperature such that the fracture toughness ratio $\left(\mathrm{K}_{\mathrm{Ic}\left(@-25^{\circ} \mathrm{C}\right)} / \mathrm{K}_{\mathrm{Ic}\left(@-5^{\circ} \mathrm{C}\right)}\right)$ was nearly constant for the ENDB, ENDC, SCB and SENB samples.
\end{abstract}

Keywords: asphalt concrete; mode I fracture toughness; geometry and loading effect; disc and beam shape specimens; bending and compressive type loads

\section{Introduction}

As a composite material, asphalt is the most used material for paving the roads. The main components of asphalt are bitumen and aggregates and due to the brittleness of mastic and fine aggregate matrix and binder at low temperatures, the behavior of this material is mainly brittle or quasi-brittle especially at low-temperature conditions [1-5].

Brittle fracture phenomenon resulting from cracking is one of the major degradation mechanisms of asphalt pavements, especially in cold regions or during the winter season. Hence, the design and manufacturing of asphalt mixture with high resistance against cracking is an achievement for the pavement engineers. Fracture toughness is an important parameter in the framework of fracture mechanics that describes the resistance of material against crack propagation [6-8]. 
Asphalt overlay containing a top-down crack is often subjected to pure mode I or crack opening failure mode and this is the most common mode of failure due to the cracking of pavement structures. Traffic loads via passing vehicles and daily or seasonal gradient temperatures or freeze-thaw cycles are two major sources of crack propagation inside the pavements (as shown schematically in Figure 1). Indeed, both thermal and mechanical loading mechanisms tend to gradually and repeatedly open the top-down crack faces initiated in the surface of the overlay. In order to assess the crack growth behavior and appropriate pavement repair time, it is necessary to know the mode I fracture toughness value $\left(\mathrm{K}_{\mathrm{IC}}\right)$ for the asphalt mixtures [9-11].



Figure 1. Pure mode I tensile cracking of the pavement induced by traffic and thermal loads.

Fracture toughness $\left(\mathrm{K}_{\mathrm{Ic}}\right)$ can be determined experimentally using suitable specimens and relevant test methods. Among the test configurations available for obtaining the $\mathrm{K}_{\mathrm{Ic}}$ value of asphalt mixtures, the following methods have received much attention by the researchers:

(i) Edge cracked rectangular beam loaded with three-point or four-point bending $[1,6,9,10,12]$;

(ii) Edge cracked circular compact tension specimen by pin loading (DCT) [1,2,13];

(iii) Edge cracked semi-circular specimen loaded with symmetric three-point bending (SCB) $[4,6,7,14-29]$;

(iv) Center cracked Brazilian disc specimen loaded with diametral compression (BD) [30,31];

(v) Edge cracked disc specimen loaded with diametral compression (ENDC) [32,33];

(vi) Edge cracked disc specimen subjected to three-point bending (ENDB) [34-42];

(vii) Edge cracked circular disc loaded with wedge splitting fixture [43];

(viii) Indirect diametral disc test [44].

The simplicity of the specimen shape and test geometry is an important issue for conducting the fracture tests on asphalt materials. In addition, the specimen and its loading type should be a good representative for the actual loading conditions that is experienced by the paving materials in the field. Laboratory specimens prepared for the mechanical tests of asphalt mixtures are often extracted from cylindrical or slab specimens (using the gyratory compactor machine, Marshall compactor machine or roller compactor machine). Thus, the majority of specimens that are used for conducting the mode I fracture toughness tests on asphalt mixtures are in the form of discs and beams. Circular and semi-circular specimens, such as the ENDB and SCB; and rectangular beam shape specimens, such as the SENB sample, are among the conventional fracture test configurations that can be easily prepared without requiring extra machining. Furthermore, all of the mentioned specimens are loaded with the conventional three-point bend fixture and can provide good 
simulations for top-down cracking phenomenon in real asphalt pavements subjected to actual traffic loads.

Based on the previous studies the fracture behavior of brittle and quasi-brittle materials and the measured mode I fracture toughness value can be noticeably affected by the type of test specimen and applied loading [45]. For example, in an investigation conducted by Aliha et al. [46] the $K_{\text {Ic }}$ values of a typical rock material obtained using some standard test specimens and procedures differ up to $40 \%$. Chao et al. [47] investigated the effect of specimen geometry on mode I fracture toughness and crack growth behavior of a brittle polymer called PMMA. Similarly, by testing different specimens subjected to three-point bend loading, Aliha et al. [48] demonstrated that the fracture toughness of plexiglass material depends on the type of specimen utilized for the testing. Furthermore, according to the previous fracture studies performed on rocks, it has been proven that the type of test specimen can noticeably affect the measured value of mode I fracture toughness [45-48]. Although the effect of mix design and asphalt ingredients on the mechanical properties and fracture behavior of asphalt mixtures has been investigated extensively [16,49-54], the influence of specimen shape and testing method has received less attention by the asphalt fracture researchers. Some testing methods such as Semi-Circular Bending (SCB) and circular Disc Compact Tension (DCT) specimens have been proposed by ASTM for determining the fracture toughness or fracture resistance of asphalt mixtures as two standard testing methods $[55,56]$. However, it is still not clear whether these two methods or other testing techniques provide the same results for the fracture toughness (as material property) of asphalt mixtures. Since such testing methods use different test geometries with different loading setups, the possible influence of geometry and loading type on the cracking resistance behavior of asphalt mixture materials is an interesting issue and it is necessary to study this topic for the asphalt concrete mixtures. The main aim of this paper is to investigate the effect of specimen geometry and loading type on the value of mode I fracture toughness of asphalt concrete mixtures. In order to achieve this purpose, a series of mode I fracture toughness experiments was performed on the same asphalt mixture with different test specimens (i.e., SCB and ENDB; and SENB and ENDC configurations). The fracture tests are conducted at two sub-zero temperatures and it is shown that although there is a general agreement and consistency between the experimental results, some differences exist in the value of determined $\mathrm{K}_{\mathrm{Ic}}$. This difference can be attributed to both the geometry (i.e., shape) of the specimen and the method of applying the loads to the samples during the fracture toughness test. However, the effect of the type of loading is more obvious than the geometry (or shape) of the test sample.

\section{Fracture Toughness Test Specimens}

Four different test specimens namely the SCB, ENDB, SENB and ENDC samples are selected for conducting the mode I fracture toughness experiments on asphalt mixture and for determining the corresponding $\mathrm{K}_{\mathrm{Ic}}$ values. Test geometry, crack location and loading configurations used for the mode I fracture testing via these samples are illustrated in Figure 2. The ENDB and ENDC specimens are disc shaped samples with radius R and thickness $t$ that contain an edge crack along the disc diameter. The depth of notch in ENDB and ENDC samples is defined by a. The SCB specimen is a semi-circular specimen with radius $R$ and thickness $t$ containing an edge crack of length $a$. The SENB specimen is a rectangular beam with the length, width and thickness of $L, W$ and $t$, respectively, that contains a vertical edge crack of length a at the middle of the beam. As seen from Figure 2, the geometry and shape of the test samples varies in terms of shape, such as full circular, semi-disc and rectangular beam. In addition, while the type of loading in the SCB, ENDB and SENB samples is three-point bending, the ENDC specimen is loaded via diametral compression force. 
(a)



(c)

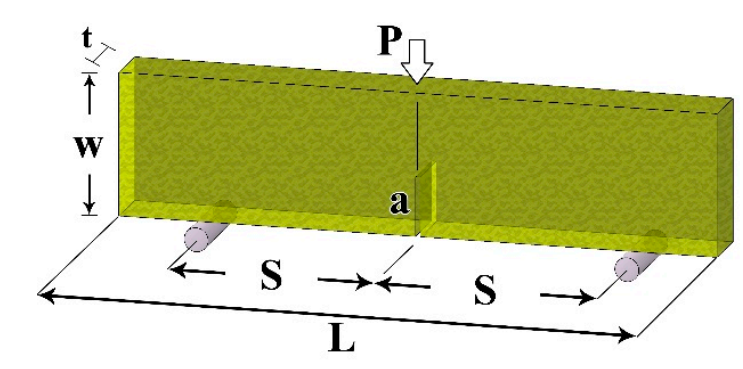

(b)



(d)

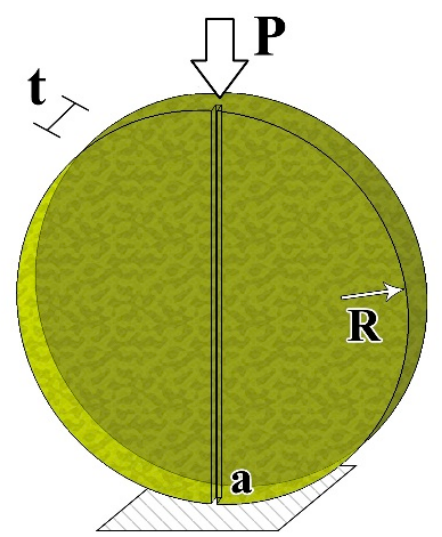

Figure 2. Description of the test specimens employed for mode I fracture toughness testing of asphalt mixture: (a) edge notch disc bend (ENDB), (b) semi-circular bend (SCB), (c) single edge notch beam (SENB) and (d) edge notch diametral compression (ENDC).

Based on the framework of Fracture mechanics, the severity of stress/strain ahead of the crack tip is explained by a well-known parameter called the stress intensity factor. This parameter, which is related to the singular term in the infinite series expansion for crack tip stress/strain field, is the most important and dominant term for describing the state of stress and determining the load bearing capacity of cracked bodies [57]. The mode-I stress intensity factor $\left(\mathrm{K}_{\mathrm{I}}\right)$ for the mentioned ENDB, SCB, SENB and ENDC samples are functions of the specimen geometry and loading condition and can be written as:

$$
\begin{gathered}
\mathrm{K}_{\mathrm{I}}(\mathrm{ENDB})=\frac{3 \mathrm{PS}}{2 \mathrm{Rt}^{2}} \sqrt{\pi \mathrm{a}} \mathrm{Y}_{\mathrm{I}}\left(\frac{\mathrm{a}}{\mathrm{t}}, \frac{\mathrm{S}}{\mathrm{R}}\right) \\
\mathrm{K}_{\mathrm{I}}(\mathrm{SCB})=\frac{\mathrm{P}}{2 \mathrm{Rt}} \sqrt{\pi \mathrm{a}} \mathrm{Y}_{\mathrm{I}}\left(\frac{\mathrm{a}}{\mathrm{R}^{\prime}}, \frac{\mathrm{S}}{\mathrm{R}}\right) \\
\mathrm{K}_{\mathrm{I}}(\mathrm{SENB})=\frac{3 \mathrm{PS}}{\mathrm{tw}^{2}} \sqrt{\pi \mathrm{a}} \mathrm{Y}_{\mathrm{I}}\left(\frac{\mathrm{a}}{\mathrm{w}}, \frac{\mathrm{S}}{\mathrm{L}}\right) \\
\mathrm{K}_{\mathrm{I}}(\mathrm{ENDC})=\frac{\mathrm{P}}{\mathrm{Rt}} \sqrt{\pi \mathrm{a}} \mathrm{Y}_{\mathrm{I}}\left(\frac{\mathrm{a}}{\mathrm{t}}\right)
\end{gathered}
$$

where $\mathrm{P}$ is the applied load and $\mathrm{Y}_{\mathrm{I}}$ is the mode $\mathrm{I}$ geometry factor that is a function of the specimen geometry (i.e., $\mathrm{a} / \mathrm{R}$ or $\mathrm{a} / \mathrm{t}$ ) and loading conditions (i.e., $\mathrm{S} / \mathrm{R}$ or $\mathrm{S} / \mathrm{L}$ ) of the ENDB, SCB, SENB and ENDC specimens [31,32,58-62]. The corresponding values of these geometry factors can be determined using finite element analysis. Figure 3 shows the finite element models of the ENDB, ENDC, SENB and SCB samples created in the ABAQUS software. The radius and thickness of disc shape samples (i.e., for ENDB, SCB and ENDC) were considered equal to $50 \mathrm{~mm}$ and $30 \mathrm{~mm}$, respectively. For the beam specimen, the corresponding values of $\mathrm{L}, \mathrm{W}$ and $t$ were considered as $400 \mathrm{~mm}, 50 \mathrm{~mm}$ and $50 \mathrm{~mm}$, respectively. Material properties (Young modulus, $E$ and Poisson's ratio $v$ ) for the models were constant and equal to $3 \mathrm{GPa}$ and $0.3 \mathrm{GPa}$, respectively. These values are typical 
values for such asphalt mixtures that have been reported and used in previous related works $[33,63,64]$. The finite element models (FEM) were created using solid C3D20 elements with total numbers of approximately 45,000 elements. Singular type elements were all used around the crack tip for producing the root singularity of stress in this region as shown in Figure 3e. For the purpose of applying the boundary conditions, rigid body contact was assumed between the loading and supporting spans and surfaces of the specimens. The finite element models of these four samples were analyzed by applying a constant reference load of $\mathrm{P}=100 \mathrm{~N}$ for each sample and the corresponding values of pure mode I stress intensity factor were determined directly via the J-integral method (built in ABAQUS code) for different crack depths and loading spans. Figure 4 shows the variations of geometry factor for pure mode I loading conditions of the analyzed samples for different $\mathrm{a} / \mathrm{R}, \mathrm{a} / \mathrm{t}, \mathrm{a} / \mathrm{W}, \mathrm{S} / \mathrm{R}$ and $\mathrm{S} / \mathrm{L}$ ratios. The results presented in Figure 4 for $Y_{\mathrm{I}}$ values were obtained by normalizing the $\mathrm{K}_{\mathrm{I}}$ values obtained from the finite element analysis of the specimens using the ABAQUS code via employing Equations (1)-(4).

(a)

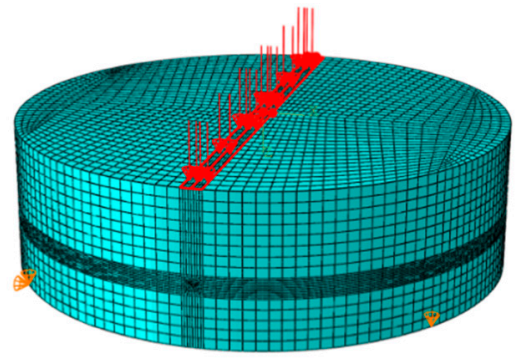

(c)
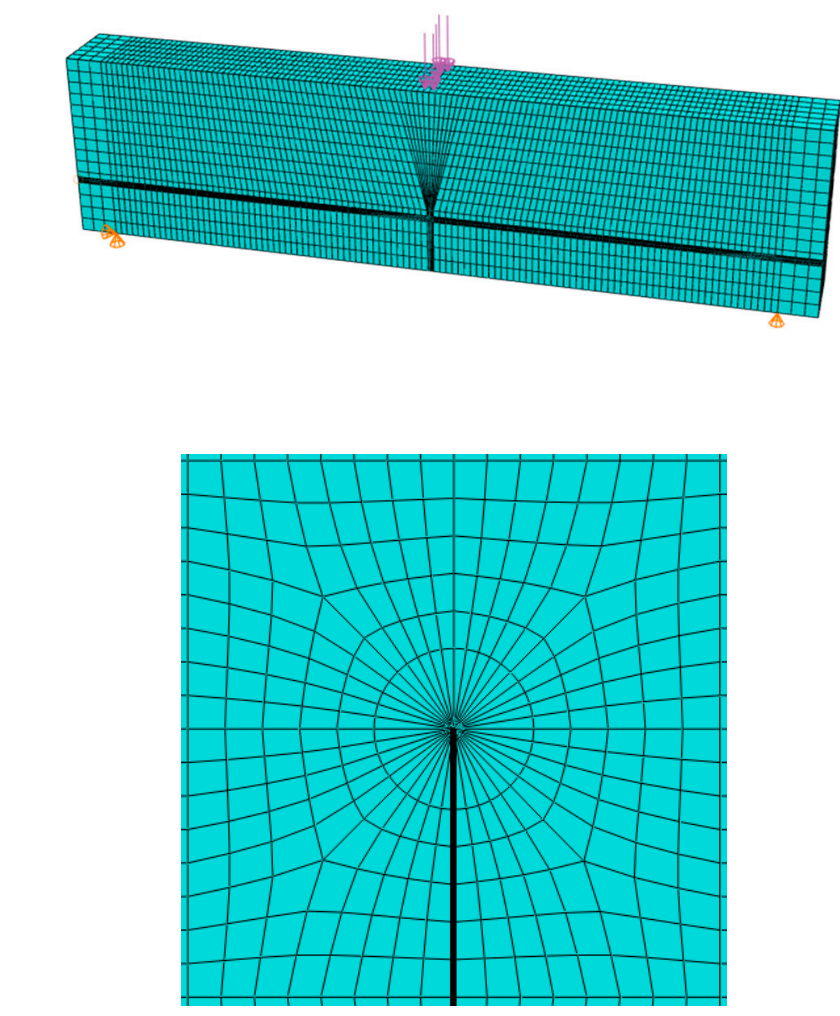

(e) (d)

(b)
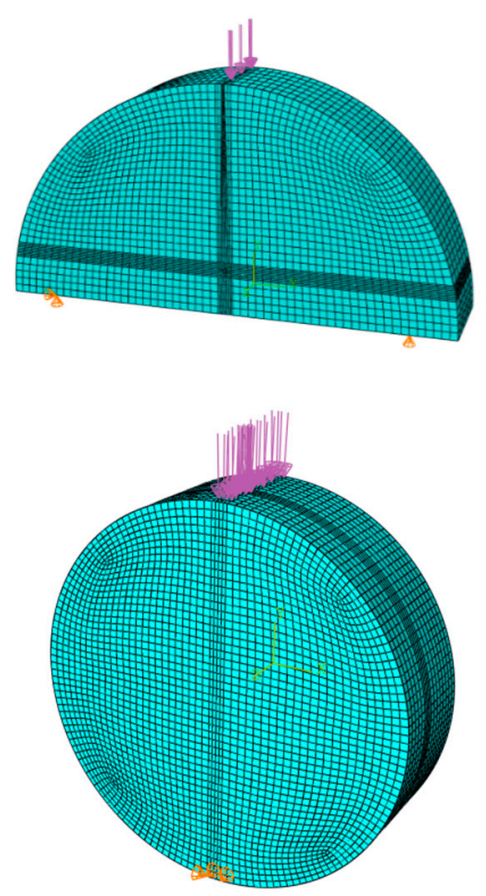

Figure 3. Finite element model of specimens subjected to mode I loading: (a) ENDB, (b) SCB, (c) SENB, (d) ENDC and (e) crack tip region modeling using singular type elements. 
(a)

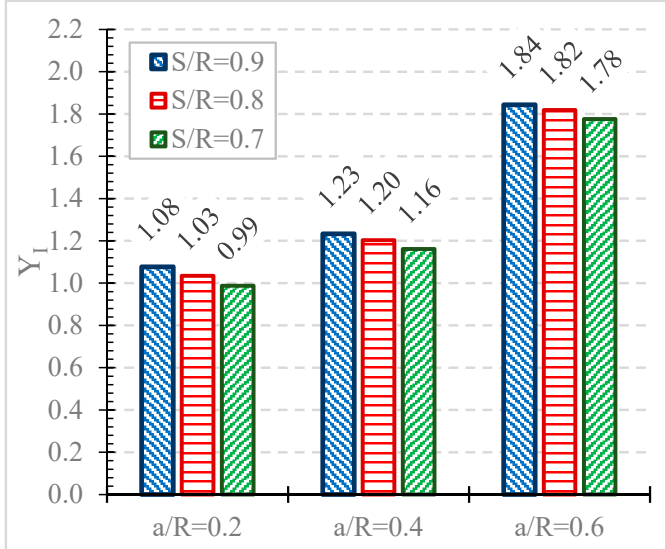

(c)

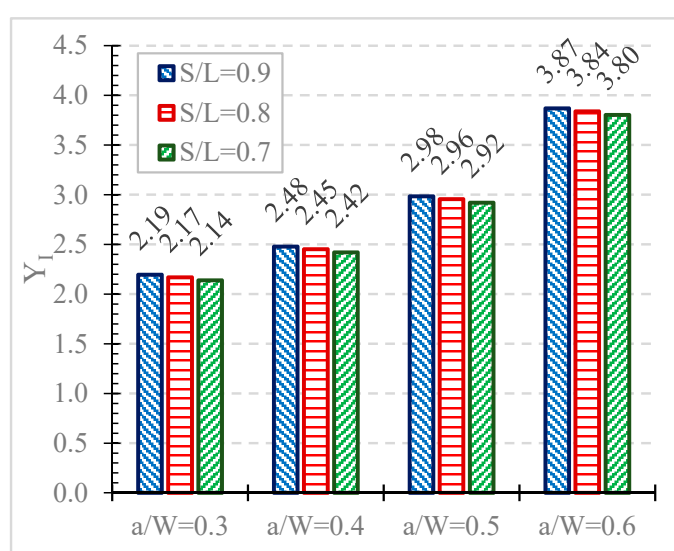

(b)

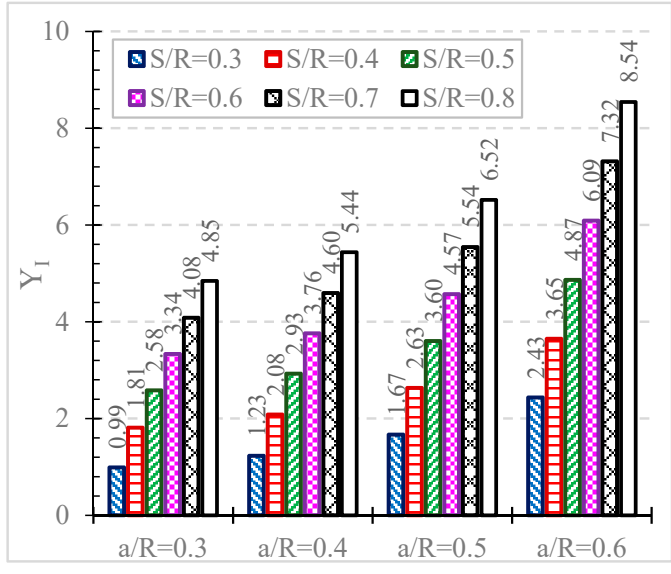

(d)



Figure 4. Variations of the mode I fracture geometry $\left(Y_{\mathrm{I}}\right)$ for different geometry and loading conditions in the analyzed test samples using ABAQUS code: (a) ENDB, (b) SCB, (c) SENB and (d) ENDC.

\section{Asphalt Mix Design}

The Hot Mix Asphalt (HMA) used in this research is composed of $60 / 70$ binder with performance grade PG (64-22) and siliceous aggregates with the nominal maximum aggregate size of $12.5 \mathrm{~mm}$. This aggregate gradation is a common sieve size for manufacturing the HMA mixture for overlaying the roads in real pavement construction projects and laboratory investigation of asphalt mixtures $[35,65]$. The physical properties of the used aggregates are mentioned in Table 1 and their gradations are illustrated in Figure 5.

Table 1. Physical properties of aggregates used for manufacturing the HMA.

\begin{tabular}{ccc}
\hline Test & Value & Test Method \\
\hline Specific gravity & $2.42 \mathrm{~g} / \mathrm{cm}^{3}$ & ASTM C-127 \\
\hline L.A. Abrasion & $23(\%)$ & AASHTO T-96 \\
\hline Absorption (coarse aggregate) & $1.5(\%)$ & AASHTO T-85 \\
\hline Absorption (fine aggregate) & $1(\%)$ & AASHTO T-84 \\
\hline Percent fracture (one face) & $98(\%)$ & ASTM D5821 \\
\hline Percent fracture (two face) & $91(\%)$ & ASTM D5821 \\
\hline
\end{tabular}

To specify the optimal percentage of bitumen, different asphalt mixtures with $4 \%, 5 \%$, $6 \%$ and $7 \%$ of bitumen content were prepared. After mixing the bitumen and aggregates, the mixtures were poured into a standard Marshall cylinder with a diameter of $100 \mathrm{~mm}$ and further compacted with a Marshall compactor (75 strokes on each side of the sample). This compaction level is often used for simulating heavy traffic conditions and the resultant 
air void content for such compacted mixture was approximately $5 \%$. Based on some key mechanical and physical parameters such as specific density, compressive strength, flow and the air void percentage, the optimum percentage of bitumen required for manufacturing the asphalt mixture used in this investigation was determined. Table 2 shows the mechanical and physical characteristics of the HMA material utilized for the preparation of the test specimens.



Figure 5. Aggregates gradations used in the current study for manufacturing asphalt mixture.

Table 2. Characteristics of manufactured HMA material.

\begin{tabular}{ccccccc}
\hline $\begin{array}{c}\text { Optimal } \\
\text { Bitumen (\%) }\end{array}$ & $\begin{array}{c}\text { Marshall } \\
\text { Resistance (kN) }\end{array}$ & Air Voids (\%) & Flow (mm) & $\begin{array}{c}\text { Unit } \\
\left.\text { Weight (Kg/m } \mathbf{m}^{\mathbf{3}}\right)\end{array}$ & VMA * (\%) & VFA ** (\%) \\
\hline 5.8 & 12.2 & 4.7 & 2.9 & 2200 & 14.6 & 67.8 \\
\hline
\end{tabular}

* Voids in mineral aggregate (VMA): the inter-granular space occupied by the asphalt and air void in a compacted mixture. ${ }^{* *}$ VFA is the percentage of voids in the compacted aggregate mass filled with the asphalt mastic.

Using the optimum bitumen percentage, the binder and aggregates were heated to $140{ }^{\circ} \mathrm{C}$ and then blended by a mixer. In order to prepare the disc shape samples (including the ENDB, ENDC and SCB specimens), the mixture was compacted by a compactor machine to produce cylindrical asphalt specimens with a diameter of $100 \mathrm{~mm}$. Although in most of the previous studies disc shape samples with a diameter of $150 \mathrm{~mm}$ obtained from the gyratory compacted asphalt cylinders have been used for manufacturing the fracture toughness test specimens, the smaller size samples (i.e., disc with a diameter of $100 \mathrm{~mm}$ ) may have some advantages, such as requiring a smaller amount of material for specimen preparation. Therefore, in some research papers disc shape specimens with a diameter of $100 \mathrm{~mm}$ were employed for conducting the fracture toughness testing of asphalt mixtures and it has been concluded that the small size test samples (i.e., $100 \mathrm{~mm}$ in diameter) can also provide valid test results for asphalt mixtures. The cylindrical samples were then sliced using a high-speed rotary diamond saw blade to obtain circular discs with the height of $30 \mathrm{~mm}$. For manufacturing the SCB sample each disc was cut along the diameter to create two semi-discs. In addition, the beam samples were manufactured by casting the mixture inside a slab mold with dimensions of $400 \times 400 \times 50 \mathrm{~mm}^{3}$. Finally, the manufactured slabs were sliced using a rotary diamond saw blade to obtain some SENB specimens with dimensions of $400 \times 50 \times 50 \mathrm{~mm}^{3}$.

Since the air void content has noticeable influence on the mechanical and strength properties of the asphalt mixtures [6], the void percentage in all prepared asphalt samples was considered constant and equal to $4.7 \%$ for the sake of comparison of the experimental results. A thin rotary diamond saw blade with a thickness of $0.5 \mathrm{~mm}$ was used to intro- 
duce an initial artificial straight edge crack in the ENDB, ENDC, SCB and SENB samples. For each specimen, eight duplicates were prepared and half of them were tested at $-5{ }^{\circ} \mathrm{C}$ and the rest of them were tested at $-25^{\circ} \mathrm{C}$. These two test temperatures (that both of them were below the lower performance grade of the utilized bitumen) were selected to investigate the effect of temperature on the low temperature fracture resistance of the HMA mixture. The difference between the temperatures was also considered high enough to ensure that the obtained results are dominantly related to the influence of test specimen and not due to the effect of other factors such as the scatter of test results and heterogeneity of asphalt samples. The prepared test samples were tested using a universal test machine at the mentioned test temperatures. The loading rate in all experiments was constant and equal to $1 \mathrm{~mm} / \mathrm{min}$. This loading rate, which has also been used in other research work [63], provides nearly static loading condition for the asphalt mixtures at low temperatures such that the HMA mixture behaves as brittle and elastic material. Figure 6 displays the sample testing setup for the tested mode I specimens.
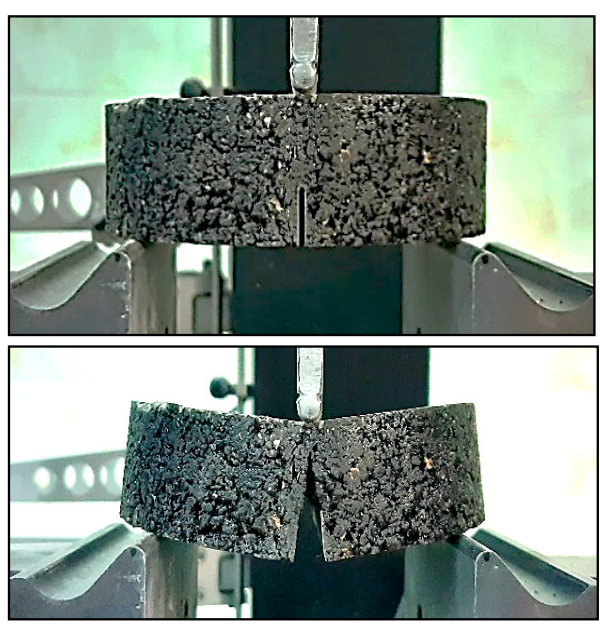

ENDB
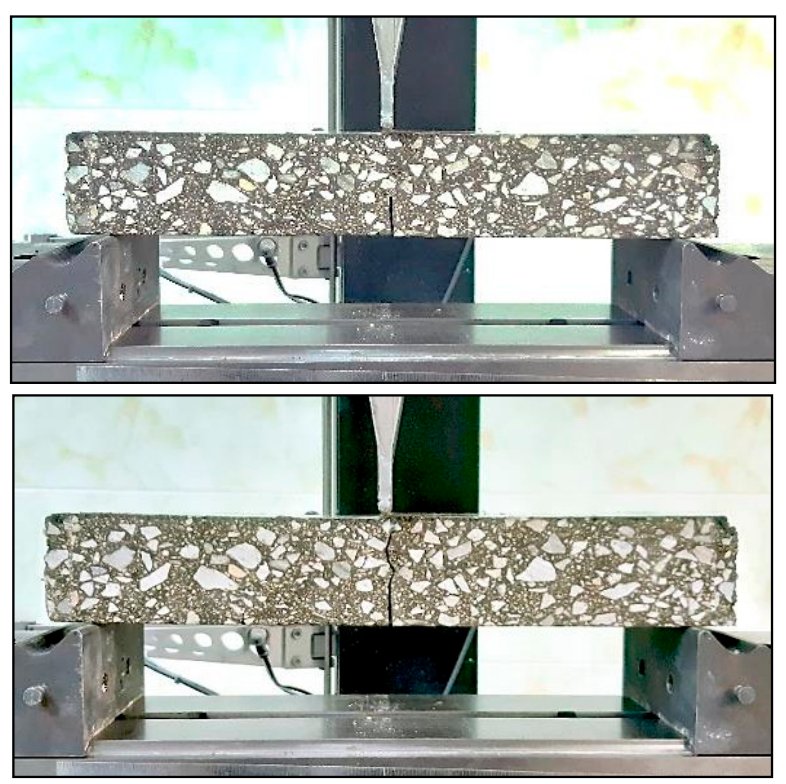

SENB
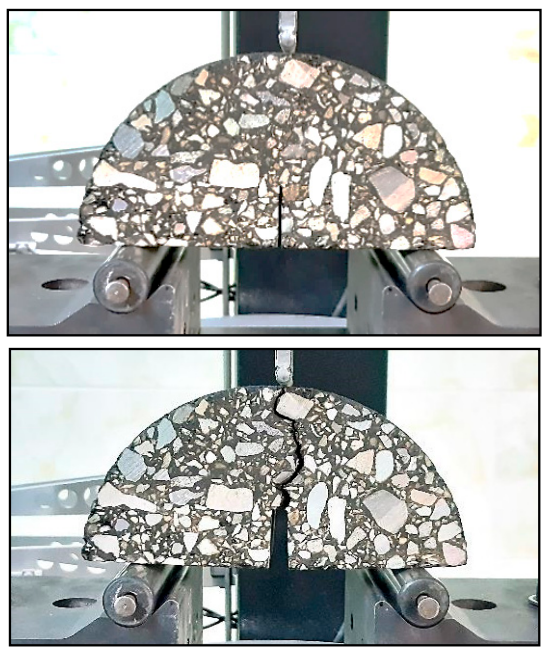

SCB
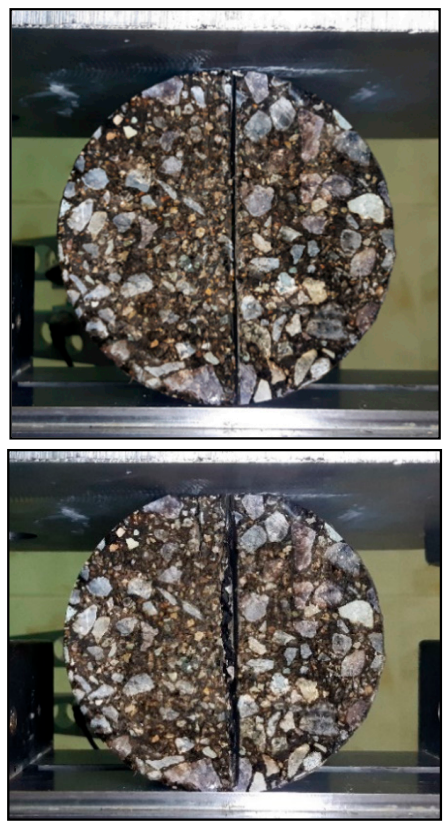

ENDC

Figure 6. Test setup (before and after failure) for conducting the fracture experiments using different test configurations. 


\section{Results and Discussion \\ 4.1. Fracture Pattern and Load-Displacement Curves}

Figure 7 shows the samples of broken ENDB, SCB, SENB and ENDC specimens fracture under mode I. It is seen that in all samples the fracture trajectory is straight without significant kinking, which extends throughout both aggregates and mastic or fine aggregate mastic. This reveals that all investigated test samples are symmetrically broken into two halves after fracturing. Comparison of the fracture trajectories of ENDB and ENDC samples that have the exact same geometry (or shape) but loaded in two different manners (i.e., bending and compression) showed that the fracturing of both samples is similar and the loading type has no effect on the fracture trajectory.

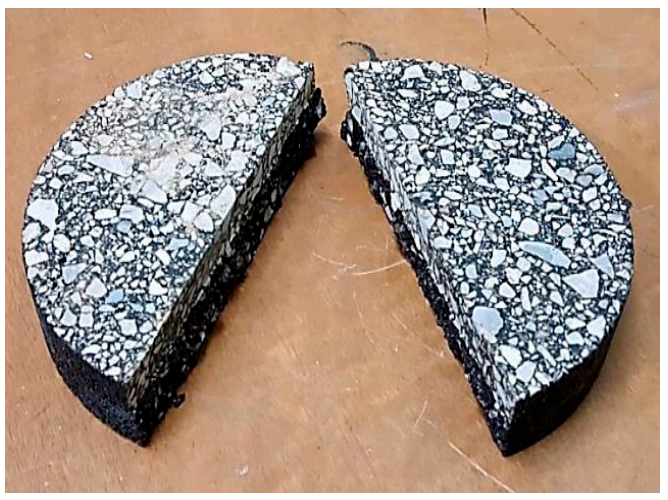

ENDB

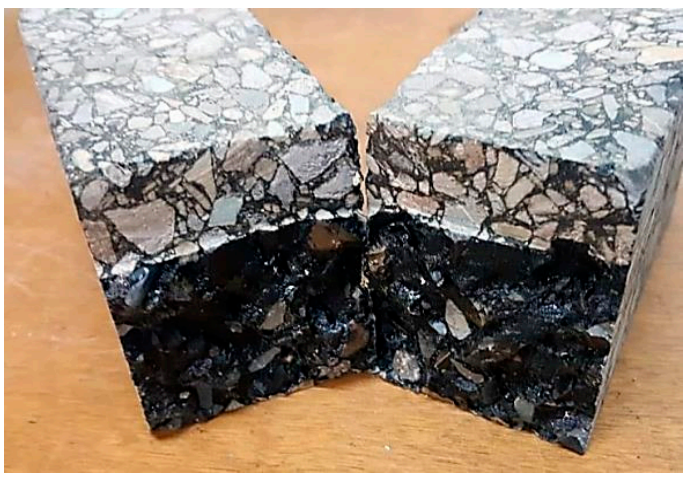

SENB

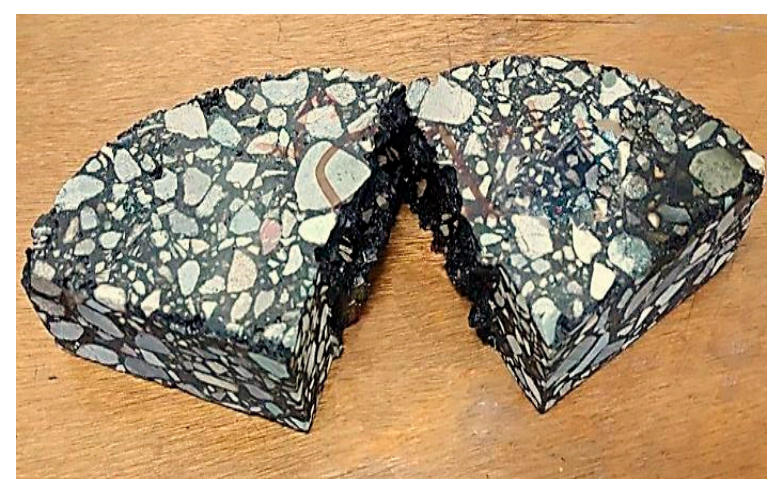

SCB

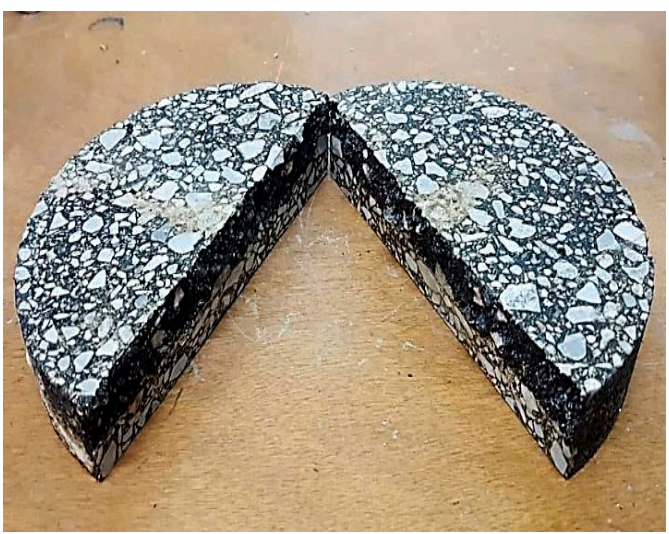

ENDC

Figure 7. Fracture trajectory and fracture surfaces observed for the tested ENDB, SCB, SENB and ENDC specimens.

However, the load bearing capacity and fracture load of the tested samples were different and this shows the effect of geometry and loading type on the fracture behavior of the asphalt mixtures. Some typical load-displacement curves obtained for the tested specimens are shown in Figure 8. From these curves it can be concluded that the low temperature fracture behavior of the tested asphalt mixture is linear and brittle and, after the peak load, a sudden drop in the loading curve is observed. The ENDC and SENB samples presented the highest and lowest fracture loads, respectively. In Table 3, the fracture loads (i.e., the maximum load values) obtained from different replicates are presented for the tested ENDB, SCB, SENB and ENDC samples at two low temperatures.

\subsection{Fracture Resistance Values of Tested Samples}

By considering the framework of Linear Elastic Fracture Mechanics (LEFM), the peak load of each sample was used for determining the fracture toughness value for the tested specimens. By replacing the corresponding values of critical fracture loads obtained from 
the experiments into Equations (1)-(4), the corresponding values of $\mathrm{K}_{\mathrm{Ic}}$ were determined. The required geometry factors $\left(\mathrm{Y}_{\mathrm{I}}\right)$ for using these equations are also presented in Table 4 for the tested conditions (determined from numerical analyses). Figure 9 presents the mode I fracture resistance (or $\mathrm{K}_{\mathrm{Ic}}$ ) value of the tested HMA material at $-25^{\circ} \mathrm{C}$ and $-5^{\circ} \mathrm{C}$.

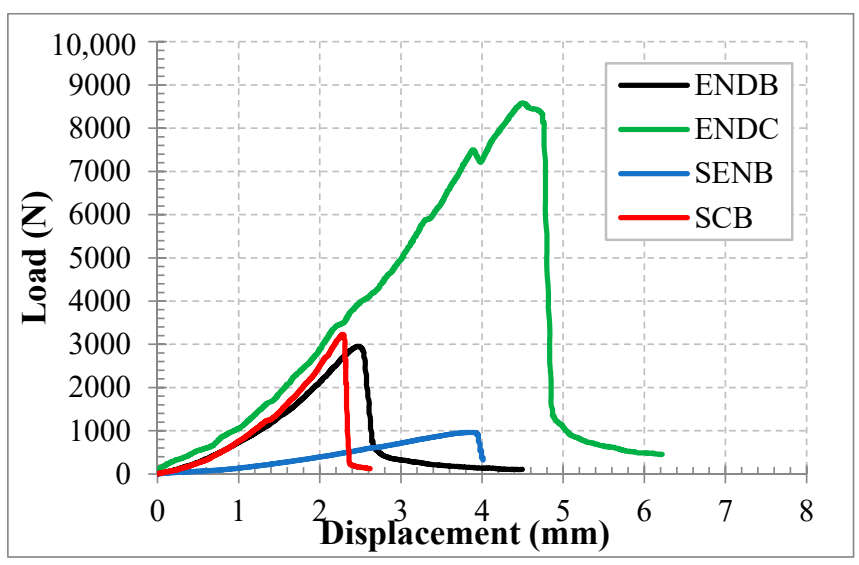

Figure 8. Typical load-displacement curves of the tested ENDB, SCB, SENB and ENDC specimens at $-25{ }^{\circ} \mathrm{C}$.

Table 3. Fracture loads of the tested specimens at low temperature conditions.

\begin{tabular}{ccccccc}
\hline \multirow{2}{*}{ Specimen } & \multirow{2}{*}{ Temperature $\left({ }^{\circ} \mathbf{C}\right)$} & \multicolumn{5}{c}{ Fracture Load (N) } \\
\cline { 2 - 6 } & & Repeat $\mathbf{1}$ & Repeat 2 & Repeat 3 & Repeat 4 & Average \\
\hline \multirow{2}{*}{ ENDB } & -25 & 2401 & 2982 & 3014 & 3091 & 2872 \\
\cline { 2 - 6 } & -5 & 1955 & 2005 & 2165 & 2218 & 2086 \\
\hline \multirow{2}{*}{ SCB } & -25 & 2926 & 3249 & 3395 & 3493 & 3266 \\
\cline { 2 - 6 } & -5 & 2252 & 2340 & 2409 & 2643 & 2411 \\
\hline \multirow{2}{*}{ SENB } & -25 & 868 & 986 & 999 & 1044 & 974 \\
& -5 & 611 & 716 & 728 & 747 & 701 \\
\hline \multirow{2}{*}{ ENDC } & -25 & 6632 & 8595 & 8814 & 9158 & 8300 \\
\cline { 2 - 6 } & -5 & 5415 & 5617 & 5739 & 6638 & 5852 \\
\hline
\end{tabular}

Table 4. Corresponding values of geometry factor $\left(\mathrm{Y}_{\mathrm{I}}\right)$ for the investigated test specimens.

\begin{tabular}{cccc}
\hline Specimen & Dimentions & Test Condition & Mode I Geometry Factor \\
\hline \multirow{2}{*}{ ENDB } & $\begin{array}{c}\mathrm{R}=50 \mathrm{~mm} \\
\mathrm{t}=30 \mathrm{~mm}\end{array}$ & $\begin{array}{r}\mathrm{S} / \mathrm{R}=0.9 \\
\mathrm{a} / \mathrm{t}=0.4\end{array}$ & $\mathrm{Y}_{\mathrm{I}}=1.25$ \\
\hline \multirow{2}{*}{$\mathrm{SCB}$} & $\begin{array}{c}\mathrm{R}=50 \mathrm{~mm} \\
\mathrm{t}=30 \mathrm{~mm}\end{array}$ & $\begin{array}{r}\mathrm{S} / \mathrm{R}=0.66 \\
\mathrm{a} / \mathrm{R}=0.33\end{array}$ & $\mathrm{Y}_{\mathrm{I}}=4.0$ \\
\hline \multirow{2}{*}{ SENB } & $\mathrm{L}=400 \mathrm{~mm}$ & $\mathrm{~S} / \mathrm{L}=0.9$ & $\mathrm{Y}_{\mathrm{I}}=0.79$ \\
& $\mathrm{~W}=50 \mathrm{~mm}$ & $\mathrm{a} / \mathrm{w}=0.5$ & \\
\hline \multirow{2}{*}{ ENDC } & $\mathrm{t}=50 \mathrm{~mm}$ & $\beta=50 \mathrm{~mm}$ & $\mathrm{Y}_{\mathrm{I}}=0.65$ \\
\hline
\end{tabular}

The fracture toughness value obtained using the ENDB and SCB specimens at $-25^{\circ} \mathrm{C}$ varies in the range between 0.87 and $1.13 \mathrm{MPa} \sqrt{ } \mathrm{m}$ and 0.89 to $1.06 \mathrm{MPa} \sqrt{ } \mathrm{m}$ with an average value of $1.05 \mathrm{MPa} \sqrt{ } \mathrm{m}$ and $0.99 \mathrm{MPa} \sqrt{ } \mathrm{m}$, respectively. The minimum and maximum band for the mode I fracture toughness obtained from the SENB specimen varies from 0.83 to $1.0 \mathrm{MPa} \sqrt{ } \mathrm{m}$ with an average value of $0.93 \mathrm{MPa} \sqrt{ } \mathrm{m}$. Similarly, from the tests conducted at $-5{ }^{\circ} \mathrm{C}$, the fracture toughness value obtained using the ENDB and SCB specimens varies 
in the range between 0.71 and $0.81 \mathrm{MPa} \sqrt{ } \mathrm{m}$ and 0.68 to $0.80 \mathrm{MPa} \sqrt{ } \mathrm{m}$ with an average value of $0.76 \mathrm{MPa} \sqrt{ } \mathrm{m}$ and $0.73 \mathrm{MPa} \sqrt{ } \mathrm{m}$, respectively. The minimum and maximum band for the mode I fracture toughness obtained from the SENB specimen varies from 0.58 to $0.71 \mathrm{MPa} \sqrt{ } \mathrm{m}$ with the average value of $0.67 \mathrm{MPa} \sqrt{ } \mathrm{m}$. The corresponding average values of $\mathrm{K}_{\mathrm{Ic}}$ for the ENDC specimen at $-25{ }^{\circ} \mathrm{C}$ and $-5{ }^{\circ} \mathrm{C}$ are also obtained equal to 0.70 and $0.49 \mathrm{MPa} \sqrt{ } \mathrm{m}$, respectively.

(a)

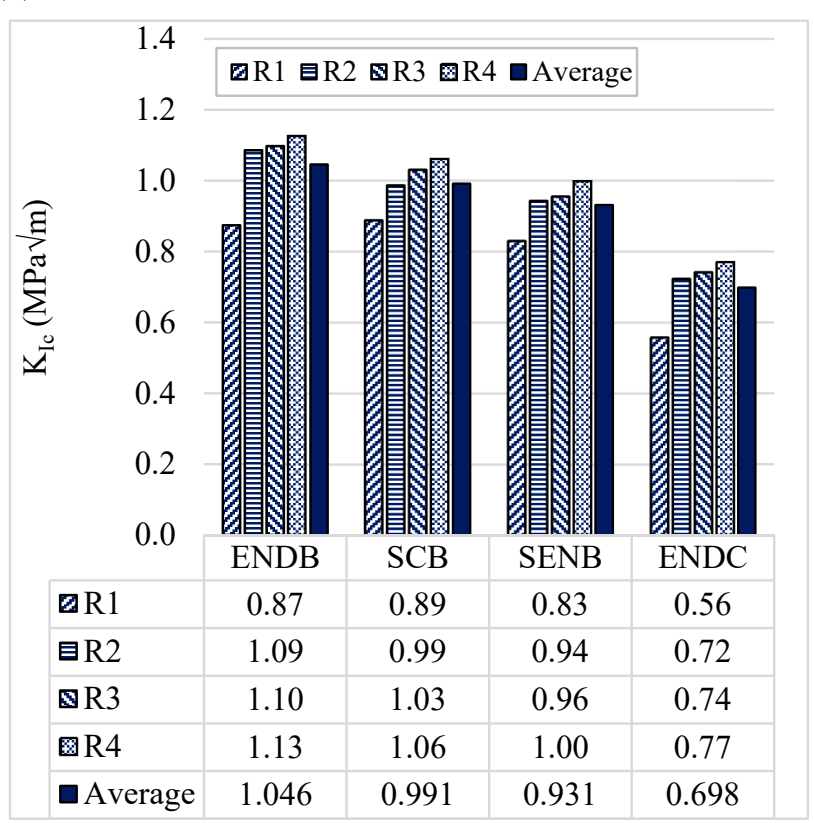

(b)

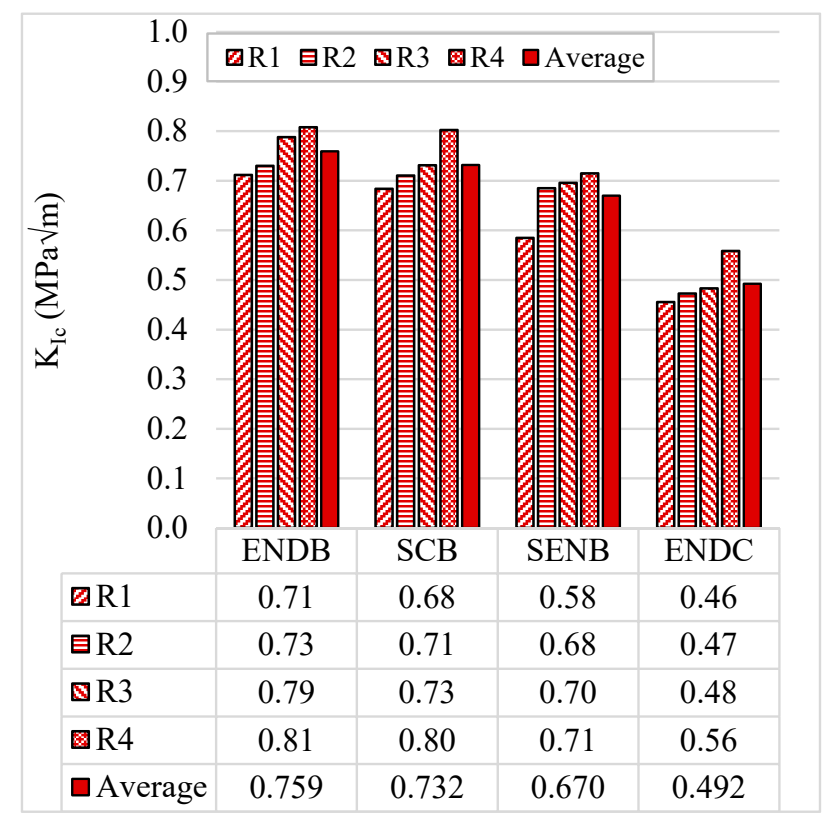

Figure 9. Fracture toughness of tested specimens under different test temperatures: $(\mathbf{a})-25^{\circ} \mathrm{C}$ and $(\mathbf{b})-5^{\circ} \mathrm{C}$.

The mode I fracture toughness values obtained in this investigation shows good consistency with the data reported by different researchers for similar HMA mixtures. The results in Table 5 compares and presents typical $\mathrm{K}_{\mathrm{Ic}}$ values reported in the literature for low temperature fracture of asphalt concrete mixtures. Depending on the type of mixture (mix design), testing temperature and type of specimen utilized for fracture toughness experiment, the value of $\mathrm{K}_{\mathrm{Ic}}$ varies in the range between 0.5 and $1 \mathrm{MPa} \mathrm{m}^{0.5}$.

The information in Figure 10 compares the corresponding values of fracture toughness obtained via four testing methods. It can be observed from Figure 10 that the results of the ENDB, SCB and SENB samples are in agreement and the $\mathrm{K}_{\mathrm{Ic}}$ values obtained using these three specimens (especially ENDB and SCB) are close together for both low temperature conditions tested in this research. The difference between the highest and lowest fracture toughness value determined from these methods is about $8 \%$. Such difference can be attributed to the geometry or shape of ENDB, SENB and SCB specimens (i.e., full disc, rectangular beam and semi-circular geometries, respectively), although the type of loading (i.e., three-point bending) is similar for all these three specimens. However, the data obtained from the ENDC specimen shows a noticeable reduction in the value of $\mathrm{K}_{\mathrm{Ic}}$ compared to the other test samples. For example, while the ENDB and ENDC samples have the exact same geometry, their $\mathrm{K}_{\mathrm{Ic}}$ values differ by approximately $20 \%$. This is mainly due to the effect of loading type (three-point bend applied to the ENDB and diametral compression applied to the ENDC specimen). Indeed, a lower bound fracture toughness value is obtained by changing the type of loading from bending to diametral compression in the edge notch disc specimen. From the obtained experimental results, it can be concluded that the fracture toughness value is more sensitive to the type of loading (i.e., bending or compression) applied to the asphalt mixture than compared to the shape of the test specimen (i.e., circular disc or rectangular beam shape). 
Table 5. Mode I fracture toughness values obtained by different researchers.

\begin{tabular}{|c|c|c|c|c|}
\hline Researcher & Temperature $\left({ }^{\circ} \mathrm{C}\right)$ & Specimen & Asphalt Type & $\begin{array}{c}\text { Fracture } \\
\text { Toughness }(\mathrm{MPa} \sqrt{ } \mathrm{m})\end{array}$ \\
\hline Aliha et al. [4] & -15 & SCB & HMA & 0.8 \\
\hline Marasteanu et al. [12] & -18 & SENB & HMA & 0.52 and 0.61 \\
\hline \multirow{2}{*}{ Aliha et al. [32] } & -15 & ENDB & HMA & 0.67 \\
\hline & -15 & ENDC & HMA & 0.54 \\
\hline \multirow{2}{*}{ Pirmohammad and Bayat [36] } & -5 & ENDB & HMA & 0.67 \\
\hline & -20 & ENDB & HMA & 0.78 \\
\hline Eghbali et al. [37] & -15 & ENDB & HMA & 0.86 \\
\hline \multirow{4}{*}{ Fuan et al. [62] } & -15 & ENDB & HMA & 0.95 \\
\hline & -15 & SCB & HMA & 0.75 \\
\hline & -25 & ENDB & HMA & 1.05 \\
\hline & -25 & SCB & HMA & 0.83 \\
\hline \multirow{2}{*}{ Shahryari et al. [66] } & -20 & ENDC & HMA & 0.65 \\
\hline & -20 & ENDB & HMA & 0.75 \\
\hline \multirow{2}{*}{ Molenaar [67] } & 0 & SCB & \multirow{2}{*}{ Dense Graded Asphalt } & 0.88 \\
\hline & -10 & SCB & & 0.98 \\
\hline
\end{tabular}

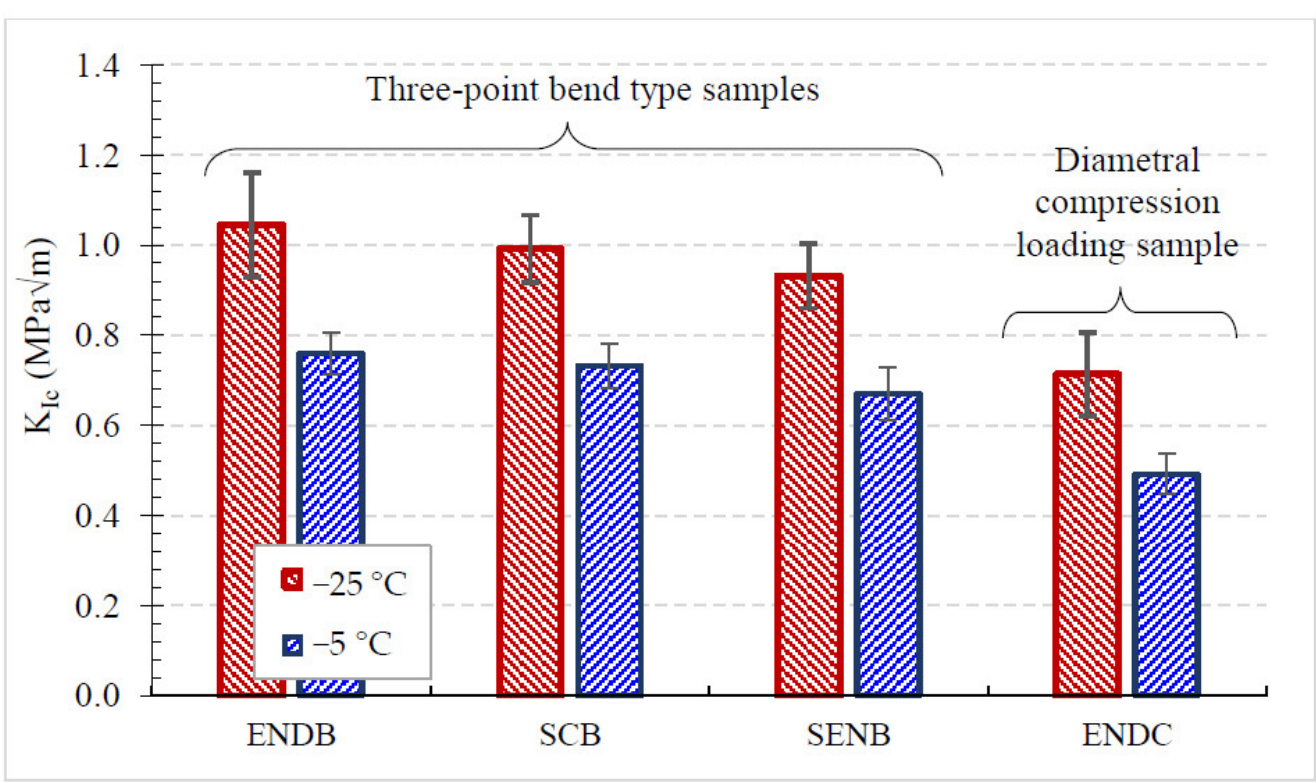

Figure 10. Comparison of fracture toughness data obtained from different mode I testing methods.

As stated earlier, the SCB test method was suggested in recent years by ASTM for measuring the fracture toughness of asphalt mixtures [55]. The information in Figure 11 shows the normalized fracture toughness ratio $\left(\mathrm{K}_{\mathrm{Ic}} / \mathrm{K}_{\mathrm{Ic}}(\mathrm{SCB})\right.$ for the tested samples. This figure reveals that the ENDB and SENB test samples can also provide nearly the same fracture toughness results as obtained by the standard SCB testing method. However, the ENDC test shows an underestimated evaluation for the resistance of asphalt mixture materials against cracking compared to the standard SCB mode I test method.

The influence of test temperature on the measured $\mathrm{K}_{\mathrm{Ic}}$ value is illustrated and compared in Figure 12a. According to this figure, which shows the variations of $\mathrm{K}_{\mathrm{Ic}}$ versus temperature, the mode I fracture toughness value is enhanced by reducing the test temperature. By decreasing the test temperature from $-5{ }^{\circ} \mathrm{C}$ to $-25^{\circ} \mathrm{C}$, in all specimens 
the $\mathrm{K}_{\mathrm{Ic}}$ values increases by approximately $40 \%$. As a viscoelastic material, the asphalt binder becomes stiffer by reducing the temperature. The stiffness of a bituminous material increases due to the reduction of temperature up to the lower performance grade temperature of bitumen. According to the literature, the stress intensity factor increases by increasing the stiffness or elastic modulus of bitumen $[27,28,68]$ and consequently such behavior can result in the increase of stiffness of the HMA mixture as well. Hence, due to the stiffer HMA mixture at $-25^{\circ} \mathrm{C}$ compared to $-5{ }^{\circ} \mathrm{C}$, the enhancement of the low-temperature crack growth resistance for asphalt mixtures is expected. Such trends observed for the variations of fracture toughness with the temperature are also reported in other published papers $[6,15,38]$. The fracture toughness ratio at two testing temperatures (i.e., $\left.\left(\mathrm{K}_{\mathrm{Ic}}\left(@-25^{\circ} \mathrm{C}\right) / \mathrm{K}_{\mathrm{Ic}}\left(@-5^{\circ} \mathrm{C}\right)\right)\right)$ are also shown in Figure $12 \mathrm{~b}$. This figure demonstrates that a simple shift occurs in the low temperature cracking resistance of the asphalt mixtures by changing the temperature. Indeed, the $\left(\mathrm{K}_{\mathrm{Ic}\left(@-25^{\circ} \mathrm{C}\right)} / \mathrm{K}_{\mathrm{Ic}}\left(@-5^{\circ} \mathrm{C}\right)\right)$ ratio changes in a narrow range for the tested geometries and specimens and it can be concluded that the $\left(\mathrm{K}_{\mathrm{Ic}\left(@-25^{\circ} \mathrm{C}\right)} / \mathrm{K}_{\mathrm{Ic}\left(@-5{ }^{\circ} \mathrm{C}\right)}\right)$ ratio is approximately equal to 1.4 as shown in Figure $12 \mathrm{~b}$.



Figure 11. Normalized mode I fracture toughness ratio $\left(\mathrm{K}_{\mathrm{Ic}} / \mathrm{K}_{\mathrm{Ic}}(\mathrm{SCB})\right.$ for the tested samples.

(a)

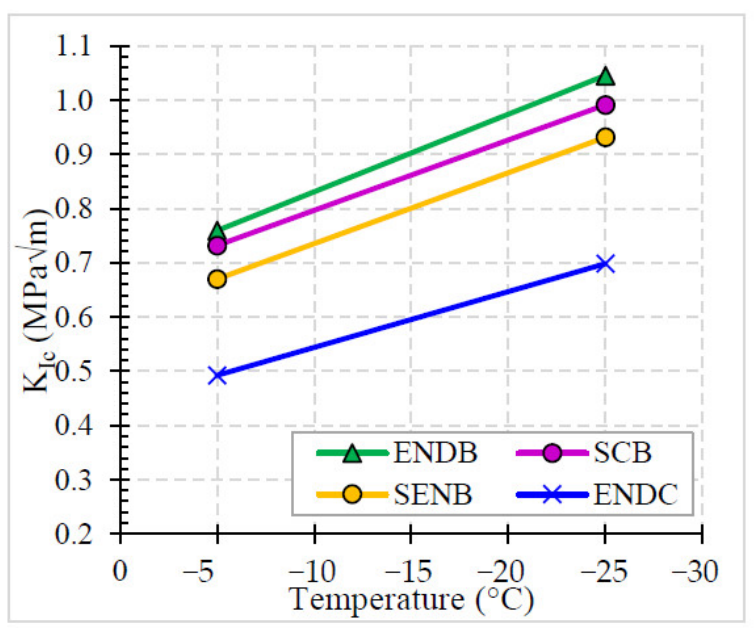

(b)



Figure 12. (a) Influence of test temperature on the measured $\mathrm{K}_{\mathrm{Ic}}$ values of HMA mixture for different mode I specimen types and $(\mathbf{b})$ fracture toughness ratio $\left(\mathrm{K}_{\mathrm{Ic}\left(@-25^{\circ} \mathrm{C}\right)} / \mathrm{K}_{\mathrm{Ic}\left(@-5^{\circ} \mathrm{C}\right)}\right)$ for the investigated mode I samples. 


\section{Conclusions}

- The average fracture toughness value obtained using the ENDB, SCB, SENB and ENDC specimens at $-25^{\circ} \mathrm{C}$ were obtained equal to $1.05,0.99,0.93$ and $0.7 \mathrm{MPa} \sqrt{ } \mathrm{m}$, respectively. Similarly, for $-5{ }^{\circ} \mathrm{C}$, the corresponding values of the average $\mathrm{K}_{\mathrm{Ic}}$ for the same mixture were $0.76,0.73,0.67$ and $0.49 \mathrm{MPa} \sqrt{ } \mathrm{m}$, respectively. These results demonstrate the effect of testing methods and temperature on the low temperature fracture resistance of asphalt mixtures.

- Results obtained from the bending type samples (ENDB, SCB and SENB specimens) were in a narrow bound and with slight differences. However, the $\mathrm{K}_{\mathrm{Ic}}$ value obtained from the ENDC (loaded in diametral compression) was noticeably less than (about 25\%) the results of other testing methods. It can be concluded that the type of the applied loading (i.e., bending or compression) has more significant effect than the shape of sample (disc or beam) on $\mathrm{K}_{\mathrm{Ic}}$ value of asphalt mixtures.

- Fracture toughness results were increased by decreasing the test temperature from $-5{ }^{\circ} \mathrm{C}$ to $-25{ }^{\circ} \mathrm{C}$ by about 40 percent. However, the fracture toughness ratio $\left(\mathrm{K}_{\mathrm{Ic}}\left(@-25^{\circ} \mathrm{C}\right) / \mathrm{K}_{\mathrm{Ic}}\left(@-5^{\circ} \mathrm{C}\right)\right)$ was nearly constant for the whole HMA tested samples under mode I with different shapes and loading conditions.

- The results of the ENDB specimen were very close to the fracture toughness obtained from the SCB specimen that is a recommended testing method by the ASTM. Therefore, among the investigated test samples the ENDB testing method can also be recommended for conducting low temperature fracture toughness test on asphalt mixtures.

Author Contributions: Conceptualization, M.R.M.A.; data curation, M.R.M.A.; formal analysis, H.R.K.; funding acquisition, D.Y.; investigation, H.R.K.; methodology, D.Y., H.R.K. and M.R.M.A.; project administration, M.R.M.A.; resources, D.Y.; supervision, M.R.M.A.; visualization, D.Y. and H.R.K.; writing—original draft, H.R.K.; writing—review and editing, M.R.M.A. All authors have read and agreed to the published version of the manuscript.

Funding: This research received no external funding.

Institutional Review Board Statement: This study did not involve tests on humans or animals.

Informed Consent Statement: Informed consent was obtained from all subjects involved in the study.

Data Availability Statement: The data presented in this study are available upon request from the corresponding author.

Conflicts of Interest: The authors declare no conflict of interest.

\section{References}

1. Wagoner, M.P.; Buttlar, W.G.; Paulino, G.H.; Blankenship, P. Investigation of the Fracture Resistance of Hot-Mix Asphalt Concrete Using a Disk-Shaped Compact Tension Test. Transp. Res. Rec. 2005, 1929, 183-192. [CrossRef]

2. Li, X.; Braham, A.F.; Marasteanu, M.O.; Buttlar, W.G.; Williams, R.C. Effect of Factors Affecting Fracture Energy of Asphalt Concrete at Low Temperature. Road Mater. Pavement Des. 2008, 9, 397-416. [CrossRef]

3. Wagoner, M.P.; Buttlar, W.G.; Paulino, G.H. Disk-shaped compact tension test for asphalt concrete fracture. Exp. Mech. 2005, 45, 270-277. [CrossRef]

4. Aliha, M.R.M.; Behbahani, H.; Fazaeli, H.; Rezaifar, M.H. Study of characteristic specification on mixed mode fracture toughness of asphalt mixtures. Constr. Build. Mater. 2014, 54, 623-635. [CrossRef]

5. Wang, C.; Zhu, Z.M.; Liu, H.J. On the I-II mixed mode fracture of granite using four-point bend specimen. Fatigue Fract. Eng. Mater. Struct. 2016, 39, 1193-1203. [CrossRef]

6. Aliha, M.R.M.; Fazaeli, H.; Aghajani, S.; Moghadas Nejad, F. Effect of temperature and air void on mixed mode fracture toughness of modified asphalt mixtures. Constr. Build. Mater. 2015, 95, 545-555. [CrossRef]

7. Mirsayar, M.; Shi, X.; Zollinger, D. Evaluation of Interfacial Bond Strength Between Portland Cement Concrete and Asphalt Concrete Layers Using Bimaterial Semicircular Bend Test Specimen. Eng. Solid Mech. 2017, 5, 293-306. [CrossRef]

8. Xu, W.; Wei, X.; Wei, J.; Chen, Z. Experimental Evaluation of the Influence of Aggregate Strength on the Flexural Cracking Behavior of Epoxy Asphalt Mixtures. Materials 2020, 13, 1876. [CrossRef]

9. Braham, A.; Buttlar, W.; Ni, F. Laboratory Mixed-Mode Cracking of Asphalt Concrete Using the Single-Edge Notch Beam. Road Mater. Pavement Des. 2010, 11, 947-968. [CrossRef] 
10. Kim, H.; Wagoner, M.P.; Buttlar, W.G. Micromechanical fracture modeling of asphalt concrete using a single-edge notched beam test. Mater. Struct. 2008, 42, 677. [CrossRef]

11. Wang, J.; Zeng, W.; Qin, Y.; Huang, S.; Xu, J. Laboratory Evaluation of Rejuvenating Agent on Reclaimed SBS Modified Asphalt Pavement. Appl. Sci. 2017, 7, 743. [CrossRef]

12. Marasteanu, M.O.; Dai, S.; Labuz, J.F.; Li, X. Determining the Low-Temperature Fracture Toughness of Asphalt Mixtures. Transp. Res. Rec. 2002, 1789, 191-199. [CrossRef]

13. Stewart, C.M.; Oputa, C.W.; Garcia, E. Effect of specimen thickness on the fracture resistance of hot mix asphalt in the disk-shaped compact tension (DCT) configuration. Constr. Build. Mater. 2018, 160, 487-496. [CrossRef]

14. Wang, H.; Zhang, C.; Li, L.; You, Z.; Diab, A. Characterization of Low Temperature Crack Resistance of Crumb Rubber Modified Asphalt Mixtures Using Semi-Circular Bending Tests. J. Test. Eval. 2016, 44, 847-855. [CrossRef]

15. Pérez-Jiménez, F.; Botella, R.; Moon, K.-H.; Marasteanu, M. Effect of load application rate and temperature on the fracture energy of asphalt mixtures. Fénix and semi-circular bending tests. Constr. Build. Mater. 2013, 48, 1067-1071. [CrossRef]

16. Aliha, M.R.M.; Behbahani, H.; Fazaeli, H.; Rezairfar, M.H. Experimental study on mode i fracture toughness of different asphalt mixtures. Sci. Iran. 2015, 22, 120-130.

17. Li, X.-J.; Marasteanu, M.O. Using Semi Circular Bending Test to Evaluate Low Temperature Fracture Resistance for Asphalt Concrete. Exp. Mech. 2010, 50, 867-876. [CrossRef]

18. Ameri, M.; Mansourian, A.; Pirmohammad, S.; Aliha, M.R.M.; Ayatollahi, M.R. Mixed mode fracture resistance of asphalt concrete mixtures. Eng. Fract. Mech. 2012, 93, 153-167. [CrossRef]

19. Aliha, M.R.M.; Fattahi Amirdehi, H.R. Fracture toughness prediction using Weibull statistical method for asphalt mixtures containing different air void contents. Fatigue Fract. Eng. Mater. Struct. 2017, 40, 55-68. [CrossRef]

20. Ameri, M.; Nowbakht, S.; Molayem, M.; Aliha, M.R.M. Investigation of fatigue and fracture properties of asphalt mixtures modified with carbon nanotubes. Fatigue Fract. Eng. Mater. Struct. 2016, 39, 896-906. [CrossRef]

21. Mubaraki, M.; Osman, S.A.; Sallam, H.E.M. Effect of RAP content on flexural behavior and fracture toughness of flexible pavement. Lat. Am. J. Solids Struct. 2019, 16. [CrossRef]

22. Mubaraki, M.; Sallam, H.E.M. Reliability study on fracture and fatigue behavior of pavement materials using SCB specimen. Int. J. Pavement Eng. 2020, 21, 1563-1575. [CrossRef]

23. Fakhri, M.; Haghighat Kharrazi, E.; Aliha, M.R.M.; Berto, F. The effect of loading rate on fracture energy of asphalt mixture at intermediate temperatures and under different loading modes. Frat. Integrita Strutt. 2018, 12, 113-132.

24. Fakhri, M.; Haghighat Kharrazi, E.; Aliha, M.R.M. Mixed mode tensile-In plane shear fracture energy determination for hot mix asphalt mixtures under intermediate temperature conditions. Eng. Fract. Mech. 2018, 192, 98-113. [CrossRef]

25. Fakhri, M.; Amoosoltani, E.; Aliha, M.R.M. Crack behavior analysis of roller compacted concrete mixtures containing reclaimed asphalt pavement and crumb rubber. Eng. Fract. Mech. 2017, 180, 43-59. [CrossRef]

26. Fakhri, M.; Ali Siyadati, S.; Aliha, M.R.M. Impact of freeze-thaw cycles on low temperature mixed mode I/II cracking properties of water saturated hot mix asphalt: An experimental study. Constr. Build. Mater. 2020, 261, 119939. [CrossRef]

27. Aliha, M.R.M.; Ziari, H.; Mojaradi, B.; Sarbijan, M.J. Heterogeneity effects on mixed-mode I/II stress intensity factors and fracture path of laboratory asphalt mixtures in the shape of SCB specimen. Fatigue Fract. Eng. Mater. Struct. 2020, 43, 586-604. [CrossRef]

28. Aliha, M.R.M.; Ziari, H.; Mojaradi, B.; Sarbijan, M.J. Modes I and II stress intensity factors of semi-circular bend specimen computed for two-phase aggregate/mastic asphalt mixtures. Theor. Appl. Fract. Mech. 2020, 106, 102437. [CrossRef]

29. Najjar, S.; Mohammadzadeh Moghaddam, A.; Sahaf, A.; Rasaei Yazdani, M.; Delarami, A. Evaluation of the mixed mode (I/II) fracture toughness of cement emulsified asphalt mortar (CRTS-II) using mixture design of experiments. Constr. Build. Mater. 2019, 225, 812-828. [CrossRef]

30. Mubaraki, M.; Elhady, A.; Sallam, H. Mixed mode fracture toughness of recycled tire rubber-filled concrete for airfield rigid pavements. Int. J. Pavement Res. Technol. 2013, 6, 8-14.

31. He, J.; Liu, L.; Yang, H.; Aliha, M.R.M.; Karimi, H.R. Contribution of Interface Fracture Mechanism on Fracture Propagation Trajectory of Heterogeneous Asphalt Composites. Appl. Sci. 2021, 11, 3013. [CrossRef]

32. Aliha, M.R.M.; Sarbijan, M.J.; Bahmani, A. Fracture toughness determination of modified HMA mixtures with two novel disc shape configurations. Constr. Build. Mater. 2017, 155, 789-799. [CrossRef]

33. Bahmani, A.; Farahmand, F.; Ataei, F.; Aliha, M.R.M. Mixed mode I/III fracture parameters for edge-notched diametrically compressed disc specimen. Mater. Des. Process. Commun. 2019, 1, e86. [CrossRef]

34. Aliha, M.R.M.; Bahmani, A.; Akhondi, S. Determination of mode III fracture toughness for different materials using a new designed test configuration. Mater. Des. 2015, 86, 863-871. [CrossRef]

35. Aliha, M.R.M.; Bahmani, A.; Akhondi, S. A novel test specimen for investigating the mixed mode I+III fracture toughness of hot mix asphalt composites-Experimental and theoretical study. Int. J. Solids Struct. 2016, 90, 167-177. [CrossRef]

36. Pirmohammad, S.; Bayat, A. Fracture resistance of HMA mixtures under mixed mode I/III loading at different subzero temperatures. Int. J. Solids Struct. 2017, 120, 268-277. [CrossRef]

37. Eghbali, M.R.; Fallah Tafti, M.; Aliha, M.R.M.; Motamedi, H. The effect of ENDB specimen geometry on mode I fracture toughness and fracture energy of HMA and SMA mixtures at low temperatures. Eng. Fract. Mech. 2019, 216, 106496. [CrossRef] 
38. Motamedi, H.; Fazaeli, H.; Aliha, M.R.M.; Reza Amiri, H. Evaluation of temperature and loading rate effect on fracture toughness of fiber reinforced asphalt mixture using edge notched disc bend (ENDB) specimen. Constr. Build. Mater. 2020, $234,117365$. [CrossRef]

39. Mansourian, A.; Hashemi, S.; Aliha, M.R.M. Evaluation of pure and mixed modes (I/III) fracture toughness of Portland cement concrete mixtures containing reclaimed asphalt pavement. Constr. Build. Mater. 2018, 178, 10-18. [CrossRef]

40. Haghighat Pour, P.J.; Aliha, M.R.M.; Keymanesh, M.R. Evaluating mode I fracture resistance in asphalt mixtures using edge notched disc bend ENDB specimen with different geometrical and environmental conditions. Eng. Fract. Mech. 2018, 190, 245-258. [CrossRef]

41. Aliha, M.R.M.; Jafari Haghighat Pour, P. Fracture resistance study for hot mix asphalt mixture under out of plane sliding mode. Eng. Fract. Mech. 2020, 238, 107230. [CrossRef]

42. Najjar, S.; Mohammadzadeh Moghaddam, A.; Sahaf, A.; Aliha, M.R.M. Low temperature fracture resistance of cement emulsified asphalt mortar under mixed mode I/III loading. Theor. Appl. Fract. Mech. 2020, 110, 102800. [CrossRef]

43. Kaloush, K.; Biligiri, K.; Zeiada, W.; Rodezno, M.; Reed, J. Evaluation of Fiber-Reinforced Asphalt Mixtures Using Advanced Material Characterization Tests. J. Test. Eval. 2010, 38, 400-411.

44. Zhang, Z.; Roque, R.; Birgisson, B. Evaluation of Laboratory-Measured Crack Growth Rate for Asphalt Mixtures. Transp. Res. Rec. 2001, 1767, 67-75. [CrossRef]

45. Aliha, M.R.M.; Sistaninia, M.; Smith, D.J.; Pavier, M.J.; Ayatollahi, M.R. Geometry effects and statistical analysis of mode I fracture in guiting limestone. Int. J. Rock Mech. Min. Sci. 2012, 51, 128-135. [CrossRef]

46. Aliha, M.R.M.; Mahdavi, E.; Ayatollahi, M.R. The Influence of Specimen Type on Tensile Fracture Toughness of Rock Materials. Pure Appl. Geophys. 2017, 174, 1237-1253. [CrossRef]

47. Chao, Y.J.; Liu, S.; Broviak, B.J. Brittle fracture: Variation of fracture toughness with constraint and crack curving under mode I conditions. Exp. Mech. 2001, 41, 232-241. [CrossRef]

48. Aliha, M.R.M.; Bahmani, A.; Akhondi, S. Mixed mode fracture toughness testing of PMMA with different three-point bend type specimens. Eur. J. Mech. A/Solids 2016, 58, 148-162. [CrossRef]

49. Pirmohammad, S.; Ayatollahi, M.R. Fracture resistance of asphalt concrete under different loading modes and temperature conditions. Constr. Build. Mater. 2014, 53, 235-242. [CrossRef]

50. Song, W.; Huang, B.; Shu, X. Influence of warm-mix asphalt technology and rejuvenator on performance of asphalt mixtures containing 50\% reclaimed asphalt pavement. J. Clean. Prod. 2018, 192, 191-198. [CrossRef]

51. Wei, M.-D.; Dai, F.; Xu, N.-W.; Liu, Y.; Zhao, T. A novel chevron notched short rod bend method for measuring the mode I fracture toughness of rocks. Eng. Fract. Mech. 2018, 190, 1-15. [CrossRef]

52. Aliha, M.R.M.; Razmi, A.; Mansourian, A. The influence of natural and synthetic fibers on low temperature mixed mode I+II fracture behavior of warm mix asphalt (WMA) materials. Eng. Fract. Mech. 2017, 182, 322-336. [CrossRef]

53. Guo, Q.; Chen, Z.; Liu, P.; Li, Y.; Hu, J.; Gao, Y.; Li, X. Influence of basalt fiber on mode I and II fracture properties of asphalt mixture at medium and low temperatures. Theor. Appl. Fract. Mech. 2021, 112, 102884. [CrossRef]

54. Somé, S.C.; Feeser, A.; Pavoine, A. Numerical and experimental investigation of mode I cracking of asphalt concrete using semi-circular bending test. Constr. Build. Mater. 2018, 169, 34-46. [CrossRef]

55. American Society for Testing and Materials. Standard Test Method for Evaluation of Asphalt Mixture Cracking Resistance Using the Semi-Circular Bend Test (SCB) at Intermediate Temperatures; D8044-16; ASTM International: West Conshohocken, PA, USA, 2016.

56. American Society for Testing and Materials. Standard Test Method for Determining Fracture Energy of Asphalt Mixtures Using the Disk-Shaped Compact Tension Geometry; D7313-20; ASTM International: West Conshohocken, PA, USA, 2020.

57. Recho, N. Fracture Mechanics and Crack Growth; ISTE; Wiley: Clermont Ferrand, France, 2012; ISBN 9781118563281.

58. Aliha, M.R.M.; Bahmani, A.; Akhondi, S. Numerical analysis of a new mixed mode I/III fracture test specimen. Eng. Fract. Mech. 2015, 134, 95-110. [CrossRef]

59. Bahmani, A.; Aliha, M.R.M.; Jebalbarezi Sarbijan, M.; Mousavi, S.S. An extended edge-notched disc bend (ENDB) specimen for mixed-mode I+II fracture assessments. Int. J. Solids Struct. 2020, 193-194, 239-250. [CrossRef]

60. Ayatollahi, M.R.; Aliha, M.R.M.; Saghafi, H. An improved semi-circular bend specimen for investigating mixed mode brittle fracture. Eng. Fract. Mech. 2011, 78, 110-123. [CrossRef]

61. Wagoner, M.P.; Buttlar, W.G.; Paulino, G.H. Development of a Single-Edge Notched Beam Test for Asphalt Concrete Mixtures. J. Test. Eval. 2005, 33, 452-460.

62. Fuan, S.; Ke, M.; Kanghe, L.; Kun, L.; Aliha, M.R.M. Influence of specimen geometry on mode I fracture toughness of asphalt concrete. Constr. Build. Mater. 2021, 276, 122181. [CrossRef]

63. Bahmani, A.; Farahmand, F.; Janbaz, M.R.; Darbandi, A.H.; Ghesmati-Kucheki, H.; Aliha, M.R.M. On the comparison of two mixed-mode I + III fracture test specimens. Eng. Fract. Mech. 2021, 241, 107434. [CrossRef]

64. Bahmani, A.; Nemati, S. Fracture resistance of railway ballast rock under tensile and tear loads. Eng. Solid Mech. 2021, 9, 271-280. [CrossRef]

65. Islam, M.R.; Kalevela, S.A.; Nesselhauf, S.K. Sensitivity of the Flow Number to Mix Factors of Hot-Mix Asphalt. Infrastructures 2019, 4, 34. [CrossRef]

66. Shahryari, N.; Keymanesh, M.R.; Aliha, M.R.M. Specimen type effect on measured low-temperature fracture toughness of asphalt concrete. Fatigue Fract. Eng. Mater. Struct. 2021, 44, 551-567. [CrossRef] 
67. Molenaar, J.M.M. Resistance to crack-growth and fracture of asphalt mixture. In Proceedings of the 6th International Rilem Symposium, Zurich, Switzerland, 14-16 April 2003; pp. 618-625.

68. Mirsayar, M.M. On the low temperature mixed mode fracture analysis of asphalt binder-Theories and experiments. Eng. Fract. Mech. 2017, 186, 181-194. [CrossRef] 